\title{
Review
}

\section{Appearances of èthos in political thought: The dimension of practical reason}

\author{
Sophia Hatzisavvidou (ed.) \\ Roman and Littlefield, 2016, x+180 pp., ISBN: 978-1783483136
}

Contemporary Political Theory (2018) 17, S102-S105. https://doi.org/10.1057/s41296017-0108-0; published online 27 March 2017

How can we think of human agency in a world driven by consumer preferences, environmental damage, and economic and political uncertainty? Is this the era of an 'anything-goes' approach or are there alternative ways of thinking about and anchoring political experience? In Appearances of Ethos in Political Thought, Sophia Hatzisavvidou argues that the concept of ethos sheds light on such questions and also allows for rethinking both the scope and meaning of political engagement. By recovering the original meaning of ethos and re-conceptualizing it as "a mode of dwelling," she seeks to formulate a democratic quality of political engagement that is defined by an "assemblage of dispositions, affects, attitudes and patterns of thinking that animate established and emerging ways of political organization and action" (p. x). For Hatzisavvidou, attending to èthos highlights "the transient yet decisive aspects of political experience that, along with established or familiar affiliation and modes of relating and acting, underpin and mobilize political engagement" (p. 21).

To develop her argument, Hatzisavvidou provides a brief conceptual history of ethos (Chapter 2) that shows how re-conceptualization as "dwelling" is productive in thinking about democratic politics. Merging the archaic meaning of ethos as topos with an active and dynamic conceptualization (p. 20), Hatzisavvidou argues that the plasticity and complexity of the term ultimately allows for denoting and connoting both "the place of life - where one dwells - and the way of life - how one dwells" (p. 2). The agents of this dwelling can be either individuals or communities; what characterizes them is their susceptibility to transformations and resourceful behavior (p. 2). Hatzisavvidou therefore defines èthos as a "complex and multifarious category, an assemblage of diverse components such as moral principles, ethical dispositions, corporeal reactions, affective responses and intellectual functions which participate in diverse ways in our perception of the world and our visions for its possible forms" (p. xii). Conceptualizing êthos as dwelling in other words enables Hatzisavvidou to argue for both a space and a mode of living where political engagement is a process of particular way of

(C) 2017 Macmillan Publishers Ltd. 1470-8914 Contemporary Political Theory Vol. 17, S2, S102-S105 
operating that seek to create change and bring "more just arrangement to the scheme of things" (p. xiii). Hatzisavvidou proposes an understanding of democratic ethos as both a "compass that orients human beings to affirm their position in the cosmic scheme of things" and a mechanism that "urges them to forge and pursue more just arrangements in it" (p. xii). Here, the agents of ethos are dwellers "who develop disparate, even competing, judgments, convictions, and practices and who shift their models of dwelling in the world as they envision and pursue new political and ecological futures" (p. xii).

In order to formulate a notion of how agents interact and effectuate change, Hatzisavvidou also proposes a reading of ethos in conjunction with two other ancient Greek concepts - kairos, which she associates with practical circumstances, and mêtis, broadly conceptualized here as resourcefulness. By highlighting the relationship and interconnections between èthos, kairos, and mêtis, Hatzisavvidou further develops the argument for èthos as "informed by affective and aesthetic experience and...situated and context-specific type of practical reasoning" (p. xi). As such, the author claims that ethos can also be understood not merely as a theoretical category that explains, but rather as a defining factor of demotic life (p. xi).

The concept of metis is critical for understanding how the agents of ethos act (Chapters 4 and 5). This is because èthos, "infused by resourcefulness," is essential for challenging hegemony and creating alternatives (p. 102). According to Hatzisavvidou, the mêtis of resourcefulness is itself "formed and informed as one engages the world politically" and is manifested through individual and collective actions and practices (p. 89). Further, mêtis provides the practical solutions and answers that allow a person (or a community) to interact with and influence the outcome of a complex situation. This form of knowledge is context-specific and capable of accounting for changing environments (i.e., operating alongside with kairos). This is also what makes it resourceful. According to Hatzisavvidou, "a resourceful, metical ethos...is more responsive to the need to negotiate and actively shape change" (p. 91).

Although there are multiple representations of mêtis in the ancient world, Hatzisavvidou mostly resorts to the figure of Protagoras (Chapter 4) to argue for the mêtis-driven type of practical reasoning and resourcefulness. Protagoras' engagement with Socrates speaks to both the capacity to negotiate and put forward political claims as well as to effectuate political change (p. 95). Here Hatzisavvidou also argues that conceptualizing the role of kairos (i.e., the opportune moment) would be insufficient. Unlike kairos, the resourcefulness associated with mêtis goes beyond the idea of "going with the flow" and allows for generating ways to exploit and transform the occasion (p. 102); it provides the means to strengthen a weak case, forward a cause which offsets the existing hegemony, and transform power relations (p. 99). The "resourceful agent" dwelling in the world that Hatzisavvidou envisions is therefore a person who understands "a shifting reality, not in order to accept and embrace it as destiny, so that she can ultimately adjust to it, but in order

(C) 2017 Macmillan Publishers Ltd. 1470-8914 Contemporary Political Theory Vol. 17, S2, S102-S105 S103 
to craft solutions to its problems, exits to its deadlock, responses to its challenges" (p. 102). Adding further to her argument, the author also makes a distinction between resourcefulness and resilience. In her conceptualization, resilience places emphasis on the process of adaptability and the management of uncertainty ( $\mathrm{p}$. 127). However, unlike resourcefulness, resilience does not embrace, but instead seeks to minimize contingency and to normalize existing social relations and political orders (p. 108). The politics of resilience therefore always "reduces the very essence of democracy, the people to a population that must be trained, prepared, and governed by experts" (p. 127).

Overall, Appearances of Ethos in Political Thought is an argument for both rethinking the meaning of contentious politics and active assertion of the need to understand the affective and time-contingent aspects of politics. Yet, the conceptualization of ethos as "dwelling," as a space and mode of living, remains rather nebulous, primarily reduced to an "êthos of resourcefulness." This is not to say that either resourcefulness or mêtis should not be linked to contentious politics. To the contrary, the author very correctly points out three primary features of mêtis that are essential for the conceptualization of politics: the refusal to succumb to an existing reality (or hegemony), the ingenious use of contingency in assessing the possibilities for transformation, and the active pursuit of change. Yet it is unclear from Hatzisavvidou's account what the parameters and limits of ethos as dwelling should be, especially in relation to democracy and justice. This becomes even more critical given the fact that the author only briefly mentions one of the major limitations of mêtis: the association of the concept with cunning and trickery. Here, instead of unpacking the complex link between mêtis and the established norms and principles, Hatzisavvidou seeks to affirm the value of mêtis as an opportunity for impact and change (p. 95).

My point in insisting on the need to address the association between mêtis and cunning is not meant to diminish the potency of using the concept in relation to politics. Rather, it is to highlight the fact that neither the ethos nor the resourcefulness that Hatzisavvidou proffers has to be associated with democratic politics. And while the agent of ethos could very well aspire to the overturning of a certain type of hegemony, the proposition to justice and change might not be aligned with either democratic or progressive agenda. A case in point is the uncanny resourcefulness (or cunning!) of Donald Trump in his rise to the US Presidency. To take this point further: could the Trump-type of resourcefulness be considered the epitome of the 'anything-goes' approach?

Another way to address the ethos-mêtis-democracy connection would be to explicate the relationship between moral and political convictions and how these inform the actions of a "resourceful dweller." However, Hatzisavvidou makes an explicit decision to not address this relationship (p. xi). The choice is perplexing given the author's own understanding of etthos as an assemblage (amongst other things) of moral principles and ethical dispositions (p. xii). It is also regretful 
because it could have further advanced our understanding of the potent, yet largely undertheorized, link between mêtis and democratic politics. The book opens up many opportunities for further exploration of contentious politics and the need to understand the affective and time-contingent aspects of politics.

Marina Kaneti

Columbia University, New York, NY 10027, USA

mk105@columbia.edu 